\title{
Role of golden jackals (Canis aureus) as natural reservoirs of Dirofilaria spp. in Romania
}

Angela Monica Ionică', loana Adriana Matei ${ }^{i *}$, Gianluca D'Amico ${ }^{1}$, Aikaterini Alexandra Daskalaki ${ }^{1}$, Jana Juránková2 Dan Traian lonescu ${ }^{3}$, Andrei Daniel Mihalca', David Modrý2, ${ }^{1,4}$ and Călin Mircea Gherman ${ }^{1}$

\begin{abstract}
Background: Dirofilaria immitis and Dirofilaria repens are mosquito-transmitted zoonotic nematodes, causing heartworm disease and skin lesions, respectively, in carnivores. In Europe, the domestic dog is apparently the main definitive host, but patent infections occur also in other species of carnivores. The rapid spread of the golden jackals (Canis aureus) throughout Europe opens a question of involvement of this species in the sylvatic cycle of pathogens in the colonised territories, including Dirofilaria spp.

Methods: Between January 2014 and May 2015, 54 golden jackals from 18 localities in Romania were examined by full necropsy for the presence of adult filarioid nematodes and blood samples from all animals were screened for the presence of microfilariae of D. immitis, D. repens and Acanthocheilonema reconditum by multiplex PCR DNA amplification.

Results: Nematodes morphologically identified as D. immitis were found in $18.52 \%$ of the animals, originating from the southern part of Romania. No D. repens or A. reconditum were found at necropsy. The molecular prevalence in blood samples from the same animals was $9.26 \%$ for D. immitis and $1.85 \%$ for D. repens. All samples were negative by PCR for A. reconditum.

Conclusion: The relatively high prevalence of Dirofilaria spp. infections in golden jackals from Romania together with the increasing density of the jackal populations highlight their potential role in the transmission of these zoonotic parasites and in the maintenance of natural disease foci.
\end{abstract}

Keywords: Wild carnivores, Reservoir, Heartworm, Dirofilariases, Dissemination, Romania

\section{Background}

The main species of Dirofilaria infecting European carnivores are $D$. immitis, a widespread nematode that causes severe cardiovascular disease (heartworm disease) [1] and D. repens, which localises sucutaneously and is associated with a variety of dermatological clinical signs [2]. Carnivores are the definitive hosts, and the parasites can be transmitted by a large variety of mosquito species (Diptera: Culicidae) [3]. The typical hosts for both species are the domestic dogs (Canis familiaris), but patent

\footnotetext{
* Correspondence: matei.ioana@usamvcluj.ro

${ }^{1}$ Department of Parasitology and Parasitic Diseases, University of Agricultural Sciences and Veterinary Medicine Cluj-Napoca, Calea Mănăştur 3-5, 400372

Cluj-Napoca, Romania

Full list of author information is available at the end of the article
}

infections have been reported also in wild canids, such as wolves (Canis lupus), red foxes (Vulpes vulpes) and golden jackals (Canis aureus) [4-6]. Mustelids are likewise involved in the epidemiology of $D$. immitis infection and their reservoir role has been demonstrated in ferrets (Mustela putorius furo) [7]. Both Dirofilaria spp. are zoonotic; however, $D$. repens is the one involved in most human cases recorded in Europe [8, 9].

Dirofilariases are widely distributed in Europe. The southern countries are historically endemic or even hyperendemic territories, and during the last decades, the infection has spread also into the north-eastern and central Europe $[9,10]$. In Romania, infections by $D$. immitis, D. repens and Acanthocheilonema reconditum have been reported in dogs and humans from different areas of the 
country [11-13]. However, despite the large populations of wild carnivores present in Romania, the role of these hosts in the spread of filarioid parasites remains unknown.

In the past decades, the populations of golden jackals in Europe underwent considerable expansion. The species originated in the Arabian Peninsula and has initially spread in three directions: westwards to Europe, to Africa and to eastern Asia [14]. More recently, this species underwent further migrations, and its current distribution range covers most of southeastern Europe and parts of eastern and central Europe, with animals occasionally being documented also to the north and the west, far from the established populations $[15,16]$. Currently, in Romania golden jackals are largely distributed throughout the country [17].

Golden jackals are known as important reservoir hosts for several parasitic and infectious diseases, many of them having medical or veterinary importance $[18,19]$. However, the importance of jackals in the epidemiology of these diseases in newly occupied territories has been poorly investigated. The goal of the present work was to assess the role of the golden jackal as wild reservoir of filarial nematodes in Romania.

\section{Methods}

Between January 2014 and May 2015, 54 legally hunted golden jackals originating from 18 localities of Romania (Fig. 1) were submitted for necropsy at the Department of Parasitology and Parasitic Diseases within the University of Agricultural Sciences and Veterinary Medicine of ClujNapoca (Romania). The carcasses were kept frozen at $-20^{\circ}$ $\mathrm{C}$ until processing. For each animal, the sex, estimated age and location of collection were recorded. Animals were aged based on upper incisive teeth wear [20] and by counting the annual rings of canine teeth cement [21]. The age categories used were juveniles (under 11 months) and adults (over 11 months), according to sexual maturity, which in the golden jackals occurs at the age of 10-11 months [22]. The subcutaneous tissue and muscular fasciae were examined for the presence of $D$. repens and $A$. reconditum. The heart, pulmonary arteries and lungs were longitudinally dissected and macroscopically examined for the evidence of $D$. immitis. All filarial nematodes were collected and identified based on morphological keys and morphometric data available in the literature [23, 24].

Additionally, clotted blood samples were taken from the heart of each examined animal and further processed by molecular methods [25]. Genomic DNA was extracted from 10 individual nematodes (one from each positive jackal) and clotted blood samples using a commercial kit (Isolate II Genomic DNA Kit, Bioline, London, UK) according to the manufacturer's instructions. PCR amplification reactions were performed as follows: for $D$. immitis a partial cytochrome $c$ oxidase subunit 1 gene (cox1, $670 \mathrm{bp}$ ) of spirurid nematodes was amplified following [26], while for blood samples a multiplex PCR discriminating three species of filarioids (D. immitis, D. repens and A. reconditum) was performed [27]. PCR products were visualised by electrophoresis in a $2 \%$ agarose gel stained with RedSafe $^{\mathrm{m}}$ 20000x Nucleic Acid Staining Solution (Chembio, St Albans, UK) and their molecular weight was assessed by comparison to a molecular marker $\left(\mathrm{O}^{\prime}\right.$ GeneRuler $^{\mathrm{m}} 100$ bp DNA Ladder, Thermo Fisher Scientific Inc., Waltham, MA, USA). PCR products were purified using a commercial kit (QIAquick PCR Purification Kit, QIAGEN, Hilden, Germany) and analysed by sequencing (performed at Macrogen Europe,

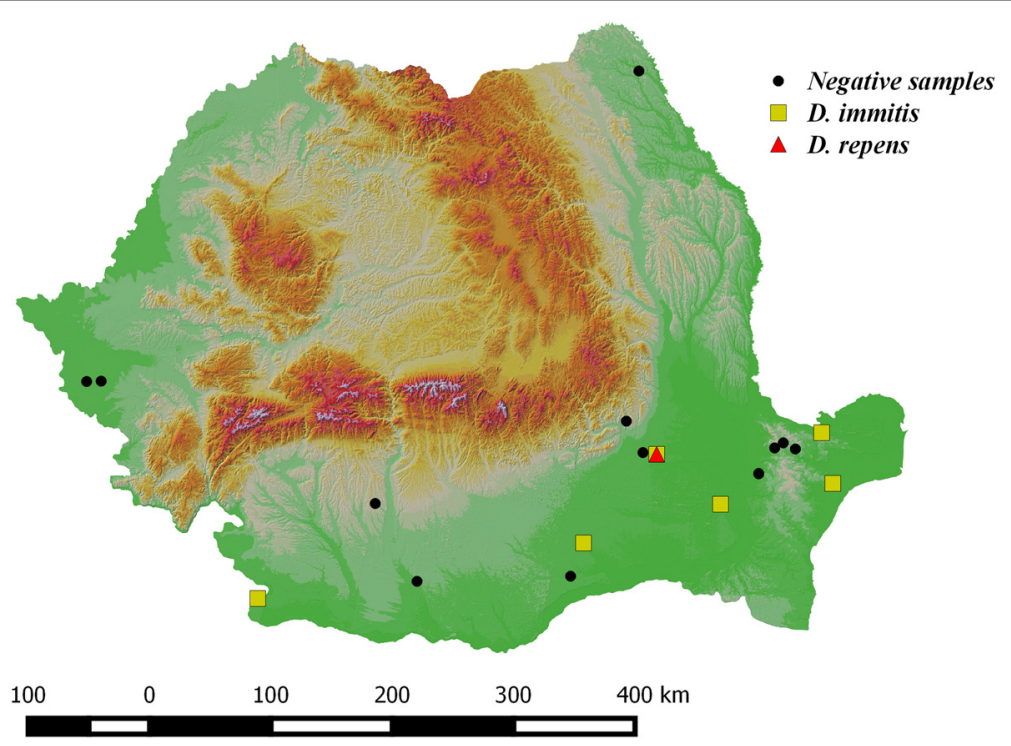

Fig. 1 Collection sites and location of positive cases 
Amsterdam). The sequences were compared to those available in the GenBank database by using Basic Local Alignment Tool (BLAST) analysis.

Statistical analysis was performed using EpiInfo ${ }^{\text {tw }} 7$ software (CDC, USA). The frequency and prevalence of infection and the $95 \%$ confidence intervals (95\% CI) were established and the differences in prevalence were assessed using chi-square testing. The differences were considered significant if $P$-values were lower than 0.05 .

\section{Results}

In total, 27 male and 27 female jackals were necropsied; 24 individuals were juveniles, while the other 30 were adults. Nematodes were retrieved from the right ventricle and pulmonary arteries of ten jackals (18.52\%; $95 \%$ CI 9.25-31.43 \%) originating from six localities (Figs. 1 and 2). The majority of infected animals were adults $(8 / 10)$ and the sex ratio was 3:2 in favor of females. The prevalence of infection was significantly higher in adults compared to juveniles $\left(\chi^{2}=2.90, d f=1, P=0.04\right)$, whereas the difference between sexes was not significant $\left(\chi^{2}=0.4909, d f=1, P=0.25\right)$. The intensity of infection varied between one and seven nematodes/ animal (mean intensity three), with seven jackals harboring at least one sexually mature pair (minimum one male and one female).

Overall, 30 nematode specimens were recovered (12 males, 18 females) and identified as D. immitis based on morphology and morphometry (Table 1). The identification was further confirmed by randomly sequencing of cox 1 from ten specimens: one from each positive animal. All sequences were identical. Representative sequence was deposited in the GenBank database (accession number KT716014) and showed a $100 \%$ similarity with strains of D. immitis collected from dogs from China and Australia (accession numbers EU159111 and AJ537512).

Five blood samples were positive by PCR for $D$. immitis (9.26 \%; 95 \% CI 4.62-15.71\%), one sample was PCR-

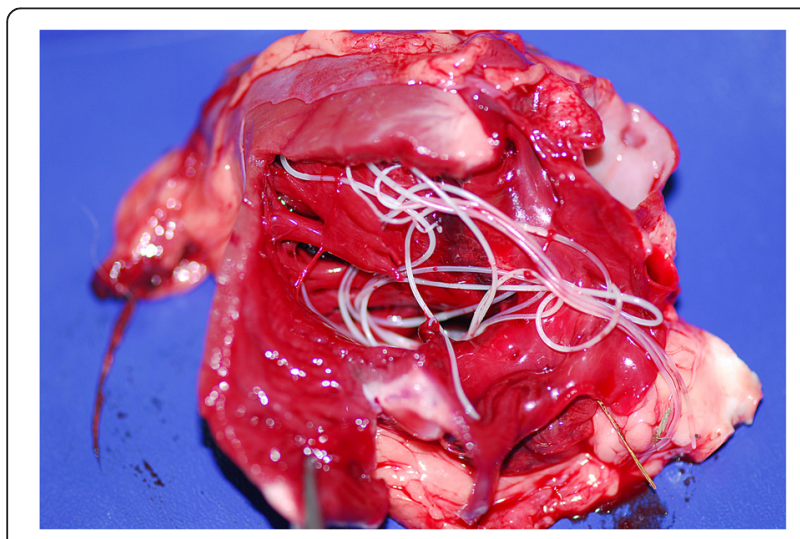

Fig. 2 Adult Dirofilaria immitis in the right ventricle of a golden jackal
Table 1 Filarioid infection in sampled animals: overall results

\begin{tabular}{|c|c|c|c|c|c|}
\hline \multicolumn{3}{|c|}{ Host } & \multicolumn{2}{|l|}{ D. immitis } & \multirow{2}{*}{$\begin{array}{l}\text { D. repens } \\
\text { PCR }\end{array}$} \\
\hline No. & Age & Sex & Necropsy & $P C R$ & \\
\hline 1 & adult & female & 2 males, 5 females & + & - \\
\hline 2 & adult & female & 2 males, 3 females & + & - \\
\hline 3 & adult & male & 1 male & - & - \\
\hline 4 & juvenile & female & 1 male, 1 female & - & + \\
\hline 5 & adult & female & 2 males & - & - \\
\hline 6 & adult & female & 1 male, 2 females & + & - \\
\hline 7 & adult & male & 1 female & - & - \\
\hline 8 & adult & male & 1 male, 1 female & + & - \\
\hline 9 & adult & female & 1 male, 3 females & + & - \\
\hline 10 & juvenile & male & 1 male, 2 females & - & - \\
\hline
\end{tabular}

positive for D. repens $(1.85 \%$; $95 \%$ CI $0.05-9.89 \%)$ and all samples were PCR-negative for A. reconditum. All five blood samples PCR positive for D. immitis. corresponded to animals which were positive also at necropsy (Table 1). We failed to amplify $D$. immitis DNA in blood from five jackals that were found positive at necropsy. In three of these cases, the golden jackals harboured only nematodes of a single sex. In the two cases when both male and female $D$. immitis were present, but with negative PCR results, the animals were juvenile and it is possible that the worms were not sexually mature yet. The prevalence of $D$. immitis infection in adult animals was significantly higher compared to juveniles $\left(\chi^{2}=2.97, d f=1, P=0.04\right)$, most likely due to a longer exposure to infected mosquitoes. Dirofilaria repens was molecularly identified in one animal $(1.86 \%)$ that was also positive for D. immitis at necropsy. The $D$. repens sequence was deposited in the GenBank database (accession number KU321603) and showed $95 \%$ similarity to other European strains of D. repens (accession numbers KR998257, KR998259, KF692102 and JF461458).

\section{Discussion}

The golden jackal is considered to be one of the most widespread wild canids. In Europe, an ongoing expansion of the Balkan populations has been recorded, their presence having been observed, with records as far west as Switzerland, as far north as Estonia and as far east as the Ukraine and the Russian Federation [15, 16]. In Romania, the first official report of this species dates from 1931, but the first anecdotal historical recording originates from the 18th Century by Dimitrie Cantemir in his work "Descriptio Moldaviae" where the golden jackal is referred to as "cical", an animal coming from the south of the Danube [28]. During the mid-20th Century, the presence of golden jackals was considered occasional, with most individuals originating from the Balkan Peninsula [29]. However, between 1950 and 2000 this species has spread throughout the country, occupying various ecosystems in eastern, southern 
and north-eastern Romania with specimens being detected in Dobrogea, Muntenia, Oltenia and also in Moldova regions $[17,28]$. More recently, golden jackals have also been hunted in western and central Romania [30,31]. Currently, this species can be found in 28 out of the 41 Romaian counties, with a national population estimated between 6431 and 8923 animals in 2013 [17, 32].

During the last decades, golden jackals have colonised and are currently present in all areas that are endemic for canine dirofilariases in Romania [13, 33-38]. The dissemination of Dirofilaria spp. is conditioned by a series of factors, mainly the existence of suitable hosts and the availability of mosquito vectors [39]. Species of mosquitoes belonging to the Culex pipiens complex, which are the most efficient natural vectors of $D$. immitis [40], and Aedes albopictus, another important natural vector for Dirofilaria spp. [41], are commonly found in the study areas $[42,43]$. Moreover, in the southern and south-eastern parts of the country, spring and summer temperatures range between 20 and $39.7^{\circ} \mathrm{C}$ [44] that are favourable for both, the development of Dirofilaria spp. and for a high density of Culex spp. [45].

In the present study, the prevalence of D. immitis infection established by necropsy was of $18.52 \%$, showing a relatively high value, compared to other post-mortem studies performed in neighbouring European countries. In Bulgaria, the recorded prevalence ranged between $4.4 \%(2 / 45)$ and $37.54 \%(122 / 325)$ [46-48]. In Hungary, $7.4 \%(2 / 27)$ of examined animals were positive [49]. In Serbia, the prevalence of $D$. immitis in golden jackals was of $7.32 \%(32 / 437)$ between 2009 and 2013 [50]. Interestingly, PCR reactions revealed a lower prevalence value $(9.26 \%)$. This discrepancy can be explained by occult (amicrofilaremic) infections, which may occur under several circumstances, such as the presence of nematodes of a single sex, prepatency of infection or immune-mediated clearance of microfilariae [51]. All individuals that tested negative for $D$. immitis by means of PCR were either harbouring nematodes of the same sex $(n=3)$ or were at juvenile age $(n=2)$, corresponding to the prepatency period, which ranges between six and nine months [52]. Additionally, in the case of mixed infection in jackal no. 4, the presence of $D$. repens together with the immune responsiveness of the host may have inhibited the production of $D$. immitis microfilariae [53].

Dirofilaria repens infections have been previously reported in golden jackals from Africa and Asia [4, 54], but this species has never been found in European golden jackals. The presence of this parasite was confirmed solely by molecular means. The adult nematodes were missed during necropsy, probably because of the abundant fat subcutaneous tissue or the extensive bullet wound. The molecular prevalence of $D$. repens was significantly lower $\left(\chi^{2}=8.1987, d f=1, P=0.004\right)$ compared to $D$. immitis.
Some authors consider that D. immitis infections in golden jackals and wolves are an epi-phenomenon of dog infection, and that they do not represent a real wild reservoir of the infection [3]. Indeed, in wolves Dirofilaria spp. infections are only sporadically reported, as individual cases $[6,50,55-57]$. Similarly, several studies suggest that red foxes are not suitable reservoir hosts for D. immitis or D. repens in some epidemiological settings $[25,49,58-60]$. Indeed, the infection in golden jackals may have originated in infected dogs inhabiting the same areas. However, the high level of patency (9.26 \%; $50 \%$ of infected animals) suggests the possibility of subsequent self-sustaining foci within the golden jackal populations. Therefore, golden jackals, due to their increased mobility and spreading, could play a significant role in disseminating Dirofilaria spp., particularly $D$. immitis.

Undoubtedly, the domestic dogs are the most abundant carnivores throughout Europe and as such, represent a dominant reservoir of Dirofilaria spp. compared to the wild canids in sympatric areas. However, in the present study the overall prevalence of $D$. immitis infection in golden jacakals exceeded that of dogs originating from the same counties (e.g. 25 vs $15.94 \%$ in Tulcea County) [13]. The high prevalece of patent $D$. immitis infections in Romanian golden jackals suggests the existence and perpetuation of a sylvatic life-cycle and highlights the importance of jackals as free-ranging resevoirs.

\section{Conclusion}

To the best of our knowledge, the present study reports $D$. repens infection in golden jackals for the first time in Europe. We highlight the relatively high prevalence of patent Dirofilaria spp. infection in golden jackals in Romania, underlining their possible role as reservoir host involved in the dissemination of these filarioids, particularly D. immitis, in their newly colonised territories.

\section{Competing interests \\ The authors declare that they have no competing interests.}

\section{Authors' contributions}

AMI and CMG wrote the manuscript, performed necropsies and morphological and morphometric analysis of D. immitis nematodes. IAM performed necropsies. AMI and IAM performed the molecular analysis. GD, AAD and JJ performed necropsies. DTI managed jackals' collection and transportation. ADM and DM coordinated the research team and critically revised the manuscript for important intellectual content. All authors read and approved the final manuscript.

\section{Acknowledgements}

We are indebted to Botond Kiss, Daniel lordache, and the hunters, who provided the carcasses. We also wish to express our gratitude to our colleagues Barbora Mitková, Anamaria Balea and Aurora Ursache, who occasionally helped with the necropsies. The research was financed from grant TE 299/2015, by UEFISCDI Grant Agency, Romania. The involvement of UVPS Brno team was further supported by project COST CZ LD14048. The work was done under the frame of EurNegVec COST Action TD1303.

\section{Author details}

${ }^{1}$ Department of Parasitology and Parasitic Diseases, University of Agricultural Sciences and Veterinary Medicine Cluj-Napoca, Calea Mănăştur 3-5, 400372 
Cluj-Napoca, Romania. ${ }^{2}$ Department of Pathology and Parasitology, University of Veterinary and Pharmaceutical Sciences, Palackého tř. 1/3, 612 42, Brno, Czech Republic. ${ }^{3}$ Department of Game and Wildlife, Faculty of Silviculture and Forestry Engineering, Transilvania University, Sirul Beethoven 1, 500123 Braşov, Romania. ${ }^{4}$ CEITEC -VFU, University of Veterinary and Pharmaceutical Sciences, Palackého tř. 1/3, 61242 Brno, Czech Republic. ${ }^{5}$ Institute of Parasitology, Biology Centre of Academy of Sciences of the Czech Republic, v.v.i., České Budějovice, Czech Republic.

\section{Received: 23 December 2015 Accepted: 20 April 2016} Published online: 28 April 2016

\section{References}

1. Simón F, Siles-Lucas M, Morchón R, González-Miguel J, Mellado I, Carretón E, Montoya-Alonso JA. Human and animal dirofilariasis: the emergence of a zoonotic mosaic. Clin Microbiol Rev. 2012;25:507-44.

2. Albanese F, Abramo F, Braglia C, Caporali C, Venco L, Vercelli A, Ghibaudo G, Leone F, Carrani F, Giannelli A, Otranto D. Nodular lesions due to infestation by Dirofilaria repens in dogs from Italy. Vet Dermatol. 2013;24:255-6.

3. Otranto D, Cantacessi C, Dantas-Torres F, Brianti E, Pfeffer M, Genchi C, Guberti V, Capelli G, Deplazes P. The role of wild canids and felids in spreading parasites to dogs and cats in Europe. Part II: Helminths and arthropods. Vet Parasitol. 2015;213:24-37.

4. Sadighian A. Helminth parasites of stray dogs and jackals in Shahsavar area, Caspian region. Iran J Parasitol. 1969;55:372-4.

5. McCall JW, Genchi C, Kramer LH, Guerrero J, Venco L. Heartworm disease in animals and humans. Adv Parasitol. 2008;66:193-285.

6. Ćircović D, Penezić A, Pavlović I, Kulišić Z, Cosić N, Burazerović J, Maletić V. First records of Dirofilaria repens in wild canids from the region of Central Balkan. Acta Vet Hung. 2014;62:481-8.

7. Campbell WC, Blair LS. Dirofilaria immitis: experimental infections in the ferret (Mustela putorius furo). J Parasitol. 1978;64:119-22.

8. Pampiglione S, Rivasi F. Human dirofilariasis due to Dirofilaria (Nochtiella) repens: an update of world literature from 1995 to 2000. Parassitologia. 2000; $42: 231-54$

9. Otranto D, Dantas-Torres F, Brianti E, Traversa D, Petrić D, Genchi C, Capelli G. Vector-borne helminths of dogs and humans in Europe. Parasit Vectors. 2013;6:16.

10. Morchón R, Carretón E, González-Miquel J, Mellado-Hernández I. Heartworm disease (Dirofilaria immitis) and their vectors in Europe - new distribution trends. Front Physiol. 2012;3:196.

11. Popescu I, Tudose I, Racz P, Muntau B, Giurcaneanu C, Poppert S. Human Dirofilaria repens infection in Romania: a case report. Case Rep Infect Dis. 2012:7:472976. doi:10.1155/2012/472976

12. Lupșe M, Mircean V, Cavasi A, Mihalca AD. Recurrent subcutaneous human dirofilariasis due to Dirofilaria repens after surgical removal of the worm and anthelmintic treatment. Parasit Vectors. 2014;7 Suppl 1:3.

13. Ionică AM, Matei IA, Mircean V, Dumitrache MO, D'Amico G, Győrke A Pantchev N, Annoscia G, Albrechtová K, Otranto D, Modrý D, Mihalca AD. Current surveys on the prevalence and distribution of Dirofilaria spp. and Acanthocheilonema reconditum infections in dogs in Romania. Parasitol Res. 2015;114:975-82.

14. Lindblad-Toh K, Wade CM, Mikkelsen TS, Karlsson EK, Jaffe DB, Kamal M, et al. Genome sequence, comparative analysis and haplotype structure of the domestic dog. Nature. 2005;438:803-19.

15. Arnold J, Humer A, Heltai M, Murariu D, Spassov N, Hackländer K. Current status and distribution of golden jackals (Canis aureus L., 1758) in Europe. Mammal Rev. 2012;42:1-11.

16. Trouwborst A, Krofel M, Linnell JDC. Legal implications of range expansions in a terrestrial carnivore: the case of the golden jackal (Canis aureus) in Europe. Biodivers Conserv. 2015;24:2593-610.

17. Papp CR, Banea OC, Szekely-Sitea Al. Applied ecology and management aspects related to the golden jackal specific ecological system in Romania. Acta Musei Maramorosiensis. 2014;9:275-92.

18. Shamir M, Yakobson B, Baneth G, King R, Dar-Verker S, Markovics A. Antibodies to selected canine pathogens and infestation with intestinal helminths in golden jackals (Canis aureus) in Israel. Vet J. 2001;162:66-72.

19. Aguirre AA. Wild canids as sentinels of ecological health: a conservation medicine perspective. Parasit Vectors. 2009;2 Suppl 1:S7.

20. Lombaard D. Age determination and growth curves in the black-backed jackal. Ann Transv Mus. 1971;27:135-69.
21. Klevezal G, Kleinenberg S. Age determination of mammals by layered structure in teeth and bone. Moscow: Nauka; 1967. in Russian.

22. Taryannikov VI. Reproduction of the jackal (Canis aureus L.) in central Asia. Ekologiya. 1976;2:107. In Russian.

23. Anderson RC, Bain O. Keys to genera of the order Spirurida. In: Anderson RC, Chabaud AG, Willmott S, editors. Keys to nematode parasites of vertebrates. Wallingford: Commonwealth Agricultural Bureau; 1976. p. 59-116.

24. Furtado AP, Melo FTV, Giese EG, dos Santos JN. Morphological redescription of Dirofilaria immitis. J Parasitol. 2010;96:499-504

25. Magi M, Calderini P, Gabrielli S, Dell'Omodarme M, Macchioni F, Prati MC, Cancrini G. Vulpes vulpes: a possible wild reservoir for zoonotic filariae. Vector-Borne Zoonotic Dis. 2008;8:249-52.

26. Casiraghi M, Anderson TJC, Bandi C, Bazzocchi C, Genchi C. A phylogenetic analysis of filarial nematodes: comparison with the phylogeny of Wolbachia endosymbionts. Parasitology. 2001;122:93-103.

27. Latrofa MS, Weigl S, Dantas-Torres F, Annoscia G, Traversa D, Brianti E, Otranto D. A multiplex PCR for the simultaneous detection of species of filarioids infesting dogs. Acta Trop. 2012;122:150-4.

28. Angelescu A. The golden jackal: origin, morphoanatomy, eco-etholgy, management. Bucharest: Editura MMC; 2004. In Romanian.

29. Vasiliu G. Verzeichnis der Säugetiere Rumäniens (Enumera ia mamiferelor din România). Säugetierkd Mitt München. 1961;9:64.

30. Dragomir FB. Sacalii în centrul Transilvaniei. Revista Vânătorul şi Pescarul Român. 2010. p. Nr. 6. In Romanian.

31. Pintea T. Șacalii din Vestul Țării. Revista Vânătorul şi Pescarul Român. 2010. p. Nr 8. In Romanian.

32. Romanian Ministry of Environment. Status of wildlife and implementation of harvesting quotas during 2006-2013. http://www.mmediu.ro/beta/wpcontent/uploads/2013/10/Situatia-efectivelor-de-fauna-si-realizarea-cotelorde-recolta-in-perioada-2006-2013.rar. Accessed Nov 2015.

33. Paşca S, Miron L, Acatrinei D, Mihalachi S. Both cardio-vasculary and subcutaneous forms of dirofilariosis in dog: a case report. In: Miron L, Mareş $M$, editors. Scientific Papers Veterinary Medicine laşi, vol. 51 2008. p. 123-7.

34. Ciocan R, Darăbuș G, Jascó O, Fok É. Detection of Dirofilaria spp. in dogs by PCR. USAMV Bull. 2010;67:40-4

35. Mircean V, Dumitrache MO, Györke A, Pantchev N, Jodies R, Mihalca AD, Cozma V. Seroprevalence and geographic distribution of Dirofilaria immitis and and tick-borne infections (Anaplasma phagocytophilum, Borrelia burgdorferi sensu lato and Ehrlichia canis) in dogs from Romania. VectorBorne Zoonotic Dis. 2012;12:595-604.

36. Ciocan R, Mederle N, Jacsó O, Tánczos B, Fok É. Autochthonous cases of Dirofilaria in dogs from Timiş County (Western Part) Romania. Global Journal of Medical Research (GJMR): (G) Veterinary Science and. Vet Med. 2013:8:29-34

37. Tudor P, Mateescu R, Tudor N. Dirofilaria infection in dogs from Târgoviște area, Romania. Curr Opin Biotechnol. 2013;24 Suppl 1:S51-2.

38. Florea Cl, Olaru S, Dobrica A, Tudor P. Epidemiologically study about natural infestation with Dirofilaria in shelters located in the Southern part of Romania. In: Proceedings of the Fourth European Dirofilaria and Angiostrongylus. Budapest: Days (FEDAD); 2014. p. 43.

39. Genchi C, Rinaldi L, Mortarino M, Genchi M, Cringoli G. Climate and Dirofilaria infection in Europe. Vet Parasitol. 2009;163:286-92.

40. Capelli G, FrangipanediRegalbono A, Simonato G, Cassini R, Cazzin S, Cancrini G, Otranto D, Pietrobelli M. Risk of canine and human exposure to Dirofilaria immitis infected mosquitoes in endemic areas of Italy. Parasit Vectors. 2013;6:60

41. Cancrini G, Scaramozzino P, Gabrielli S, Di Paolo M, Toma L, Romi R. Aedes albopictus and Culex pipiens implicated as natural vectors of Dirofilaria repens in central Italy. J Med Entomol. 2007;44:1064-6.

42. Nicolescu G, Vladimirescu A, Ciolpan O. The distribution of mosquitoes in Romania (Diptera: Culicidae). Part I: Anopheles, Aedes and Culex. Eu Mosquito Bull. 2002;13:17-26.

43. Dinu S, Cotar Al, Pănculescu-Gătej IR, Fălcută E, Prioteasa FL, Sîrbu A, Oprişan G, Bădescu D, Reiter P, Ceianu CS. West Nile virus circulation in South-Eastern Romania, 2011 to 2013. Euro Surveill. 2015;20:6.

44. Gâştescu P. The Danube Delta biosphere reserve. Geography, biodiversity, protection, management. Rev Roum Géogr. 2009;53:139-52.

45. Manzoor F, Nasir A, Fazal S. Population dynamics of different mosquito species at Lahore College For Women University Campus, Lahore. J Mosq Res. 2013;3:82-8. 
46. Georgieva D, Kirkova Z, Ivanov A. A study on the incidence and diagnosis of dirofilariosis (heartworm disease) in carnivores. Bulg J Vet Med. 2001;4:231-6.

47. Kirkova Z, Ivanov A, Georgieva D. Dirofilariosis in dogs and wild carnivores in Bulgaria. In: Genchi C, Rinaldi L, Cringoli G, editors. Mappe

Parassitologiche 8 - Dirofilaria immitis and D. repens in dog and cat and human infections. Naples: Rolando Editore; 2007. p. 204.

48. Panayotova-Pencheva MS, Mirchev RL, Trifinova AP. Dirofilaria immitis infection in carnivores from Bulgaria: 2012-2013 update. Bulg J Vet Med. 2015. doi:10.15547/bjvm.918.

49. Tolnai Z, Széll Z, Sproch Á, Szeredi L, Sréter T. Dirofilaria immitis: an emerging parasite in dogs, red foxes and golden jackals in Hungary. Vet Parasitol. 2014;203:339-42.

50. Penezić A, Selaković S, Pavlović I, Ćirović D. First findings and prevalence of adult heartworms (Dirofilaria immitis) in wild carnivores from Serbia. Parasitol Res. 2014;113:3281-5.

51. Rawlings CA, Dawe DL, McCall JW, Keith JC, Prestwood AK. Four types of occult Dirofilaria immitis infection in dogs. J Am Vet Med Assoc. 1982;180:1323-6.

52. Manfredi MT, Di Cerbo A, Genchi M. Biology of filarial worms parasitizing dogs and cats. In: Genchi C, Rinaldi L, Cringoli G, editors. Mappe Parassitologiche 8 - Dirofilaria immitis and D. repens in dog and cat and human infections. Naples: Rolando Editore; 2007. p. 41-5.

53. Genchi C, Solari Basano F, Bandi C, Di Sacco B, Venco L, Vezzoni A, Cancrini G. Factors influencing the spread of heartworms in Italy: interaction between Dirofilaria immitis and Dirofilaria repens. In: Proceedings of Heartworm Symposium '95. Batavia: American Heartworm Society; 1995. p. 65-71.

54. Myers BJ, Kuntz RE, Wells WH. Helminth parasites of reptiles, birds, and mammals in Egypt VII. Check list of the nematodes collected from 1948-1955. Can J Zool. 1962:40:531-8.

55. Segovia JM, Torres J, Miquel J, Llaneza L, Feliu C. Helminths in the wolf, Canis lupus, from north-western Spain. J Helminthol. 2001;75:183-92.

56. Pascucci I, Fico R, D'Angelo AR, Serini S, Camma C. First notification in Italy of cardiopulmonary filariosis (heartworm disease) in a wolf (Canis lupus). Vet Ital. 2007:43:851-8.

57. Shimalov W, Pen'kevich VA. Helminth fauna of the wolf (Canis lupus Linnaeus, 1758) in Belorussian Polesie. Parazitologiya. 2012;46:118-26. In Russian.

58. Marconcini A, Magi M, Macchioni G, Sassetti M. Filariosis in foxes in Italy. Vet Res Comm. 1996:20:316-9.

59. Magi M, Guardone L, Prati MC, Mignone W, Macchioni F. Extraintestinal nematodes of the red fox Vulpes vulpes in north-west Italy. J Helmithol. 2015;89:506-11.

60. Härtwig V, Schulze C, Pfeffer M, Daugschies A, Dyachenko V. No evidence of Dirofilaria repens infection in red foxes (Vulpes vulpes) and raccoon dogs (Nyctereutes procyonoides) from Brandenburg, Germany. Parasitol Res. 2016:115:867-71.

\section{Submit your next manuscript to BioMed Central and we will help you at every step:}

- We accept pre-submission inquiries

- Our selector tool helps you to find the most relevant journal

- We provide round the clock customer support

- Convenient online submission

- Thorough peer review

- Inclusion in PubMed and all major indexing services

- Maximum visibility for your research

Submit your manuscript at www.biomedcentral.com/submit

) Biomed Central 